\title{
Influence of transient processes on organic carbon remineralization pathways and rates in the West Gironde Mud Patch (Bay of Biscay, Northeast Atlantic)
}

\author{
NICOLAS DUBOSQ ${ }^{1}$, BRUNO DEFLANDRE ${ }^{1}$, SYLVAIN \\ RIGAUD $^{2}$, ANTOINE GRÉMARE ${ }^{1}$, BASTIEN LAMARQUE ${ }^{1}$, \\ MARCIO M.B. TENORIO ${ }^{3}$, MARIE-ANGE CORDIER ${ }^{4}$, \\ DOMINIQUE POIRIER ${ }^{1}$ AND SABINE SCHMIDT ${ }^{4}$ \\ ${ }^{1}$ Université de Bordeaux, CNRS, EPOC, EPHE, UMR 5805 \\ ${ }^{2}$ Univ. Nîmes, EA 7352 CHROME, rue du Dr Georges Salan, \\ 30021 Nîmes, France \\ ${ }^{3}$ Federal University of Rio de Janeiro \\ ${ }^{4}$ CNRS, Université de Bordeaux, EPOC, EPHE, UMR 5805 \\ Presenting Author: nicolas.dubosq@u-bordeaux.fr
}

At the global scale, it is estimated that 50 to $80 \%$ of continental organic matter inputs to the ocean are remineralized on continental margins. Characterizing their functioning is therefore essential to improve the understanding of global biogeochemical cycles in a changing ocean. The West Gironde Mud Patch is a mid-shelf silty clay area located in the Bay of Biscay (Northeast Atlantic) where sedimentary processes are influenced by Gironde fluvial inputs, hydrodynamics (waves, tidal currents), bottom trawling and bioturbation. All these processes are likely to modify sedimentary organic carbon remineralization pathways and rates. To determine the intensity of these degradation processes and factors controlling their spatiotemporal variabilities, profiles of porosity, grain-size, particulate (reactive $\mathrm{Fe}$ and $\mathrm{Mn}$, organic carbon (OC), pigments) and dissolved $\left(\mathrm{O}_{2}, \mathrm{NO}_{3}{ }^{-}, \mathrm{NH}_{4}{ }^{+}, \mathrm{Fe}(\mathrm{II}), \mathrm{Mn}(\mathrm{II}), \mathrm{SO}_{4}{ }^{2-}\right)$ chemical species were measured at five stations along a cross-shelf transect between 2016 and 2018 (four JERICObent cruises, French Oceanographic Fleet). Our results indicate that the main organic carbon degradation pathways are aerobic respiration and sulfate reduction. Despite a high intra-station variability (from 14 to $75 \%$ ), aerobic respiration tends to be higher at the most distal site (up to $76 \mathrm{mgOC} \mathrm{m}^{-2} \mathrm{~d}^{-1}$ ). On the contrary, the intensity of sulfate reduction decreases from 20 to $3 \mathrm{mgOC} \mathrm{m}^{-2} \mathrm{~d}^{-1}$ seaward. The highest sulfate reduction rate, assessed at the shallowest site, is related to a decimeter-thick transient sandy layer overlying relic muddy sediments within which sulfate is the main available oxidant. At the other sites, changes in remineralization intensity appear associated with the quantity and quality of particulate organic matter as well as with biomixing activities. At seaward sites, depth profiles of reactive $\mathrm{Fe}$ and $\mathrm{Mn}$ along with the large number of burrows suggest that bioirrigation activities could cause transient redox oscillations, thus promoting suboxic degradation processes, which are therefore likely underestimated. In April 2018, an increase of total remineralization rates (i.e. all degradation pathways confounded) from 40 to $160 \%$ according to sites was triggered by fresh organic matter inputs related to the spring bloom. We attribute this stimulation of remineralization processes in part to priming effects. 